\title{
Extracellular Tannase from Aspergillus ochraceus: Influence of the Culture Conditions on Biofilm Formation, Enzyme Production, and Application
}

\author{
Fernanda Mansano Aracri ${ }^{1}$, Rayza Morganna Farias Cavalcanti ${ }^{1}$, and Luis Henrique Souza Guimarães ${ }^{2 *}$ \\ ${ }^{1}$ Instituto de Química de Araraquara - UNESP. Avenida Professor Mário Degni s/n ${ }^{\circ}$ Quitandinha, Araraquara, São Paulo 14800-900, Brazil \\ ${ }^{2}$ Faculdade de Filosofia, Ciências e Letras de Ribeirão Preto - USP. Avenida Bandeirantes 3900, Monte Alegre, Ribeirão Preto, São Paulo \\ 14040-901, Brazil
}

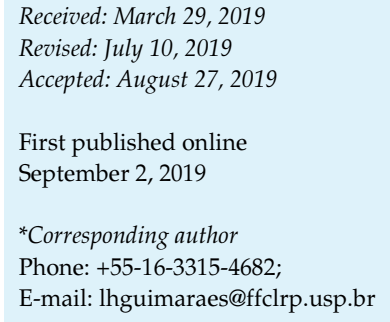

\begin{abstract}
Aspergillus ochraceus biofilm, developed on an inert support, can produce tannase in Khanna medium containing $1.5 \%(\mathrm{w} / \mathrm{v})$ tannic acid as the carbon source, at an initial $\mathrm{pH}$ of 5.0 , for $72 \mathrm{~h}$ at $28^{\circ} \mathrm{C}$. Addition of $0.1 \%(\mathrm{w} / \mathrm{v})$ yeast extract increased enzyme production. The enzyme in the crude filtrate exhibited the highest activity at $30^{\circ} \mathrm{C}$ and $\mathrm{pH} 6.0$. At $50^{\circ} \mathrm{C}$, the half-life was $60 \mathrm{~min}$ and $260 \mathrm{~min}$ at $\mathrm{pH}$ 6.0. In general, addition of detergents and surfactants did not affect tannase activity significantly. Tannase has potential applications in various biotechnological processes such as the production of propyl gallate and in the treatment of tannin-rich effluents. The content of tannins and total phenolic compounds in effluents from leather treatment was reduced by $56-83 \%$ and $47-64 \%$, respectively, after $2 \mathrm{~h}$ of enzyme treatment. The content of tannins and total phenolic compounds in the sorghum flour treated for $120 \mathrm{~h}$ with tannase were reduced by $61 \%$ and $17 \%$, respectively. Interestingly, the same A. ochraceus biofilm was able to produce tannase for three sequential fermentative process. In conclusion, fungal biofilm is an interesting alternative to produce high levels of tannase with biotechnological potential to be applied in different industrial sectors.
\end{abstract}

Keywords: Biofilm fermentation, fungal biofilm, leather effluent, tannase, tannin acyl hydrolase

\section{Introduction}

Tannins are polyphenolic compounds with high molecular mass and comprise an important and heterogeneous group of secondary metabolites found in different plant species [1]. In some plants, these compounds play an important role in the defense mechanism against attacks from herbivores and microbial infections. Interestingly, some microorganisms have developed the capacity to hydrolyze tannins to tannic acid [2]. Tannins form reversible and irreversible links with proteins, nucleic acids, saccharides, alkaloids, and minerals. Traditionally, these molecules are classified into hydrolyzable tannins and condensed tannins. Hydrolyzable tannins are characterized by the presence of a saccharide core esterified with phenolic acids such as gallic and hexahydroxydiphenic acids. Condensed tannins, also known as proanthocyanidins, have higher molecular mass than hydrolyzable tannins and are non-branched polymers of flavonoid units [1]. However, under the modern classification, tannins have been divided into four main groups: gallotannins, ellagitannins, condensed tannins, and complex tannins [3].

Polyphenolic compounds have vast applications in different industrial sectors. In the wine industry, tannins are responsible for some organoleptic properties of the beverage [4]. In the animal nutrition industry, tannins can affect ruminants positively or negatively depending on type, structure, molecular mass, and quantity [1]. Owing to their ability to form complexes with various molecules, including digestive enzymes, tannins can reduce the bioavailability of nutrients and, consequently, the nutritional quality of the feed [5]. They are also used in leather 
industries to treat large volumes of tannin-rich effluents that pollute the environment [6].

The above-mentioned problems can be solved using enzyme technology, an eco-friendly process. Tannases (tannin acyl hydrolase; E.C. 3.1.1.20) are enzymes that catalyze the breakdown of ester and depsidic bonds of gallotannins and ellagitannins to form glucose and gallic acid or ellagic acid, respectively [5, 7]. Complex tannins can also be hydrolyzed by tannases [8]. In general, tannases have been reported to be inducible enzymes. However, the production can be influenced differently by different carbon sources such as arabinose, glucose, and fructose. For example, production of tannase by Paecilomyces variotii can be stimulated by glucose, but repressed by other carbon sources that include arabinose, raffinose, and xylose [9].

Tannases have potential application in different areas. They are widely used during instant tea processing to minimize the formation of insoluble precipitates at low temperatures [10]. Addition of tannase to feed formulations for animals can improve animal digestibility and nutrient intake [11]. Tannases also can be used in the production of wine. During the vinification, precipitates are generated when the wine is maintained at low temperatures. This negative effect of tannins can be avoided by tannase use. Another important application of the enzyme is in the production of gallic acid, the precursor for trimethoprim (synthesis in the pharmaceutical industry) and propyl gallate substance used as an additive in the food industry and as an antioxidant in oils and lipid-rich products [5]. Additionally, the use of tannases to treat tannin-rich effluents produced by leather industry has also been demonstrated [12].

These enzymes can be obtained from different sources, especially microorganisms such as filamentous fungi. Tannase can be produced from filamentous fungi by submerged fermentation (SbmF) or solid-state fermentation (SSF) [5]. Another way to produce fungal enzymes is through the fungal biofilm technology. This method of production has been described previously in cellulase production by Aspergillus niger described by GutierrezCorrea et al. (2012) [13], phytase production from Rhizopus microspores described by Sato et al. (2016) [14], and $\beta$ fructofuranosidase production by $A$. japonicus described by Mussato et al. (2009) [15]. Fungal biofilm fermentation combines both submerged and solid-state fermentation, allowing high production of biomolecules such as enzymes. The growth of fungus on an organic or inert support is similar to that in the natural environment. For every microorganism, the gene expression varies with the type of fermentation. Previous reports have demonstrated the production of some enzymes using this new fermentation method. However, this is the first report on the production of tannase by biofilm fermentation using A. ochraceus biofilm and its potential application in biotechnology.

\section{Material and Methods}

\section{Microorganism}

A. ochraceus is deposited in the fungal culture collection of the Laboratory of Microbiology and Cell Biology of the Faculdade de Filosofia, Ciências e Letras de Ribeirão Preto from the University of São Paulo, Brazil. It was maintained in potato dextrose agar (PDA) slants at $4^{\circ} \mathrm{C}$.

\section{Developing Biofilms and Electron Microcopy Analysis}

Fungal biofilms were developed using $2.3 \mathrm{~cm} \times 2.3 \mathrm{~cm}$ polyethylene as an inert support. These supports were immersed in an aqueous spore suspension $\left(10^{6}\right.$ spores $\left./ \mathrm{ml}\right)$, maintained for $2 \mathrm{~h}$ under agitation at $50 \mathrm{rpm}$, at $28^{\circ} \mathrm{C}$ to promote the adhesion of spores to the support. Then, the supports were removed using sterile tweezers and each one was washed twice with distilled water for $30 \mathrm{~min}$ at $50 \mathrm{rpm}$ at $28^{\circ} \mathrm{C}$ to remove the unadhered spores. The supports containing adhered spores, were introduced into different Erlenmeyer flasks each containing different culture medium such as Khanna [16], Mineral [17], SR [18], Czapeck [19], and M5 [20] with $2 \%(w / v)$ glucose as an additional carbon source. The flasks were maintained at $28^{\circ} \mathrm{C}$ and $50 \mathrm{rpm}$ for different time periods (24-72 h).

The biofilms obtained in Khanna medium were prepared for the electron microcopy analysis. First, the biofilms were dehydrated throughout aqueous solutions with increasing concentration of ethanol (10-90\%, v/v) and absolute ethanol. Then, the biofilms were coated with colloidal gold and analyzed using Zeiss EVO 50 (UK).

\section{Production of Tannase Using Biofilms}

Initially, the biofilms obtained as described above were inoculated in $125 \mathrm{ml}$ Erlenmeyer flasks containing $25 \mathrm{ml}$ of the same culture media but supplemented with $1 \%(\mathrm{w} / \mathrm{v})$ tannic acid as a carbon source to induce the production of tannase, for $72 \mathrm{~h}$, at $28^{\circ} \mathrm{C}$ and $50 \mathrm{rpm}$. The biofilms were also inoculated in Khanna medium containing different additional carbon sources as carbohydrates (w/v: $1 \%$ sucrose, $2 \%$ glucose, $1 \%$ lactose, and $1 \%$ maltose), dried plant leaves (m/v: $1 \%$ green tea and $1 \%$ mint), $1 \%$ $(\mathrm{w} / \mathrm{v})$ tannic acid, and $1 \%(\mathrm{w} / \mathrm{v})$ gallic acid. The influence of cultivation period $(24-120 \mathrm{~h})$, initial $\mathrm{pH}$ of the culture medium (4.0-7.0), and the nitrogen source (w/v: $0.1 \%$ beef extract, peptone, yeast extract and casein) on the tannase production by A. ochraceus biofilm using Khanna medium under $50 \mathrm{rpm}$ was analyzed. After cultivation, the biofilms were removed from the media and the broth was harvested under vacuum filtration using 
the Whatman No.1 filter paper. The free cell filtrate was named as extracellular crude extract and was used for the determination of tannase activity.

\section{Determination of Tannase Activity and Protein Quantitation}

Tannase activity was determined using methanolic rhodanine methodology as described by Sharma et al. (2000) [21], using $0.2 \%$ $(\mathrm{w} / \mathrm{v})$ methyl gallate as substrate in $100 \mathrm{mmol} \mathrm{l}^{-1}$ sodium acetate buffer, $\mathrm{pH}$ 5.0. The reaction mixture was composed of $250 \mu \mathrm{l}$ of substrate solution and $250 \mu \mathrm{l}$ of enzymatic sample. It was incubated at $30^{\circ} \mathrm{C}$ for $5 \mathrm{~min}$. The reaction was stopped by the addition of $300 \mu \mathrm{l}$ of $0.667 \%(\mathrm{w} / \mathrm{v})$ methanolic rhodamine and, after $5 \mathrm{~min}$, followed by the addition of $200 \mu \mathrm{l}$ of $0.5 \mathrm{~N}$ potassium hydroxide and $4 \mathrm{ml}$ of distilled water. After $10 \mathrm{~min}$, the reaction samples were quantified in a spectrophotometer with wavelength adjusted to $520 \mathrm{~nm}$. One unit of tannase activity (U) was defined as the amount of enzyme necessary to produce $1 \mu \mathrm{mol}$ gallic acid per minute under the assay conditions.

The protein quantification was done according to Bradford methodology [22] using bovine serum albumin (BSA) as standard. The concentration of protein was expressed as $\mathrm{mg} / \mathrm{ml}$ of sample. One unit of specific activity was defined as $\mathrm{U} / \mathrm{mg}$ of protein in the sample.

\section{Influence of the Temperature and $\mathrm{pH}$ on the Tannase Activity}

The influence of temperature range $\left(20-85^{\circ} \mathrm{C}\right)$ and the $\mathrm{pH}$ range 3.0-9.0 using $100 \mathrm{mmol} \mathrm{l}^{-1}$ citric acid buffer (pH 3.0-4.0), $100 \mathrm{mmol}^{-1}$ sodium acetate buffer ( $\mathrm{pH} 5.0-6.0), 100 \mathrm{mmol} \mathrm{l}^{-1}$ Tris- $\mathrm{HCl}$ buffer ( $\mathrm{pH}$ 7.0-8.0), and $100 \mathrm{mmol}^{-1}$ glycine buffer ( $\mathrm{pH} 9.0$ ) on tannase activity was evaluated.

\section{Influence of Different Compounds on Tannase Activity}

The effect of $1 \mathrm{mmol} \mathrm{l}^{-1} \beta$-mercaptoethanol, urea, EDTA, 0.01\% (v/v) detergents (SDS, Triton X-100, and Tween-20), and 1\% (v/v) organic solvents (methanol, ethanol, acetonitrile, acetone, isopropanol, and n-butanol) on tannase activity was analyzed.

\section{Production of Propyl Gallate}

The production of propyl gallate through the transesterification reaction performed by the tannase from $A$. ochraceus was analyzed using Fourier transform infrared (FTIR) spectroscopy. The reaction mixture was composed of $5 \mathrm{mmol} \mathrm{l}^{-1}$ tannic acid in $100 \mathrm{mmol}^{-1}$ MES buffer at $\mathrm{pH}$ 6.0, and 1-propanol at 1:1 (v/v). The reactions were conducted for different time periods (24-96 h) at $30^{\circ} \mathrm{C}$. The FTIR spectra were obtained using Bruker Vertex 70 Bruker spectrophotometer equipped with attenuated total reflection (ATR) accessory. Propyl gallate (Sigma) was used as standard. The software used was the OPUS 7.5, with a scan time of 64 scans between $4,000 \mathrm{~cm}^{-1}$ to $400 \mathrm{~cm}^{-1}$ and spectral resolution of $4 \mathrm{~cm}^{-1}$. These analyses were carried out in the Laboratory of Multiuser of Chemical Analyzes of the Chemistry Institute of Araraquara (UNESP).

\section{Treatment of Leather Effluent}

The effluent samples were obtained from the Cooperativa dos Curtidores e Artesãos em Couro de Ribeira de Cabaceiras (ARTEZA), District of Ribeira, Cabaceiras, Paraíba, Brazil. Two types of effluents were used: one, obtained from the mechanized hide treatment and another, from manual treatment. In the former, the treatment was conducted using soybean and cotton oils along with tannin powder from angico (Anadenanthera colubrina (Vell.)). In the manual process, the treatment is done using only angico bark in a tank for 15 days.

For the enzymatic treatment, the crude filtrate containing tannase was added to the effluent samples at $1: 1(\mathrm{v} / \mathrm{v})$ and the mixture was maintained at $30^{\circ} \mathrm{C}$ for $2 \mathrm{~h}$. After this period, the treated effluents were analyzed for concentration of tannins and total phenolic compounds.

\section{Determination of Tannins and Total Phenolic Compounds}

The quantification of tannins was performed according to Hagerman and Butler (1978) [23]. The reaction was done using $500 \mu \mathrm{l}$ of the treated sample and $1 \mathrm{ml}$ of BSA solution prepared in $0.2 \mathrm{~mol} \mathrm{l}^{-1}$ sodium acetate buffer, $\mathrm{pH} 5.0$ and maintained at $27^{\circ} \mathrm{C}$ for $15 \mathrm{~min}$. Thereafter, the material was centrifuged at 2,800 $\times \mathrm{g}$ for $15 \mathrm{~min}$. The supernatant was discharged, and the pellet was solubilized in $750 \mu \mathrm{l}$ of $1 \%$ SDS (w/v) with $1.5 \mathrm{ml}$ of SDStriethanolamine solution, and $500 \mu \mathrm{lof} \mathrm{FeCl}_{3}$. The solution was maintained at $27^{\circ} \mathrm{C}$ for $20 \mathrm{~min}$. The absorbance was monitored at $510 \mathrm{~nm}$. A standard curve of tannic acid $(0-0.2 \mathrm{mg} / \mathrm{ml})$ was used as reference.

The quantification of total phenolic compounds was done according to Rao et al. (2018) [24]. The reaction mixture was constituted by $125 \mu \mathrm{l}$ of the sample, $125 \mu \mathrm{l}$ of the Folin-Ciocalteu reagent, and $500 \mu \mathrm{l}$ of distilled water. After $6 \mathrm{~min}$ of incubation in a dark room at $27^{\circ} \mathrm{C}, 1.5 \mathrm{ml}$ of sodium carbonate solution $(7 \%, \mathrm{w} / \mathrm{v})$, and $1 \mathrm{ml}$ of distilled water were added and maintained for $90 \mathrm{~min}$ at $27^{\circ} \mathrm{C}$ in a dark room. The absorbance was monitored at $725 \mathrm{~nm}$ and a standard curve of gallic acid $(0-0.2 \mathrm{mg} / \mathrm{ml})$ was used as reference.

\section{Treatment of the Sorghum Grains}

The sorghum grains were purchased from a local market and crushed to obtain the sorghum meal. It was used for the treatment process with extracellular crude extract obtained from the biofilm fermentation which contained tannase. Crude filtrate $(0.5 \mathrm{ml})$ was added to $25 \mathrm{ml}$ Erlenmeyer flasks containing $1 \mathrm{~g}$ of sorghum meal and maintained for $120 \mathrm{~h}$ at $30^{\circ} \mathrm{C}$, as described by Schons et al. (2012) [25]. For control, the crude filtrate was replaced by distilled water.

After enzymatic treatment, the sorghum meal samples were extracted with $70 \%(\mathrm{v} / \mathrm{v})$ methanol at a proportion of 20:1 (w/v) for $2 \mathrm{~h}$ at $25^{\circ} \mathrm{C}$ at $200 \mathrm{rpm}$. Then, the material was centrifuged at $1320 \times g$ for $15 \mathrm{~min}$ at $5^{\circ} \mathrm{C}$. The supernatant was used for determination of total phenolic compounds and tannins. The 
samples without enzymatic treatment were also submitted for extraction.

\section{Results and Discussion}

\section{Production of Tannases by A. ochraceus Biofilm}

Among the media used for biofilm development, best results were obtained using the Khanna medium and the Mineral medium. The A. ochraceus biofilm was also obtained using Czapeck medium, but with inferior biomass (1.31 g) when compared to that using Khanna (2 g) and Mineral (2.94 g) media. When SR and M5 media were used, fungal growth was reduced, and the biofilm was not obtained. The differences observed in the formation of biofilm in each medium can be justified by the differences in compositions of these media. Some salts present in Khanna and Mineral media can be essential for fungal development and their absence in the other media can negatively affect biofilm formation.

According to these results, biofilms were developed using both Khanna and Mineral media and transferred to different culture media for the enzyme production (Table 1). The highest enzyme production was obtained using the biofilm which was developed in Khanna medium and transferred to a new Khanna medium containing tannic acid as carbon source $(0.25 \mathrm{U} / \mathrm{ml}$ and $7.35 \mathrm{U} / \mathrm{mg}$ of protein). Under this condition, the enzyme production by A. ochraceus biofilm was 7 -fold higher than that reported by

Table 1. Production of extracellular tannase by A. ochraceus biofilm, developed in Khanna and Mineral media, using different culture media.

\begin{tabular}{clcc}
\hline \multirow{2}{*}{$\begin{array}{c}\text { Media of } \\
\text { biofilm } \\
\text { growth }\end{array}$} & $\begin{array}{c}\text { Media of } \\
\text { tannase } \\
\text { production }\end{array}$ & $\mathrm{U} / \mathrm{ml}$ & $\begin{array}{c}\mathrm{U} / \mathrm{mg} \text { of } \\
\text { protein }\end{array}$ \\
\cline { 3 - 4 } Khanna & M5 & $0.09 \pm 0.00$ & $0.65 \pm 0.50$ \\
& Czapeck & $0.05 \pm 0.03$ & $3.05 \pm 2.41$ \\
& SR & $0.09 \pm 0.00$ & $1.00 \pm 0.02$ \\
& Mineral & $0.02 \pm 0.00$ & $0.67 \pm 0.06$ \\
& Khanna & $0.25 \pm 0.03$ & $7.35 \pm 0.88$ \\
& M5 & $0.05 \pm 0.00$ & $0.64 \pm 0.00$ \\
& Czapeck & $0.13 \pm 0.01$ & $4.35 \pm 0.97$ \\
& SR & $0.12 \pm 0.02$ & $3.10 \pm 0.24$ \\
& Mineral & $0.03 \pm 0.00$ & $1.49 \pm 0.74$ \\
& Khanna & $0.16 \pm 0.00$ & $5.31 \pm 0.05$ \\
\hline
\end{tabular}

The biofilms were developed in Khanna and Mineral media containing $2 \%(\mathrm{w} / \mathrm{v})$ glucose as the carbon source. The media for enzyme production were added with $1 \%(\mathrm{w} / \mathrm{v})$ tannic acid as the carbon source. The cultures were maintained at $28^{\circ} \mathrm{C}$ under agitation (50 rpm) for $72 \mathrm{~h}$.
Gonçalves et al. (2012) [26] using Khanna medium added with tannic acid as carbon source for submerged fermentation. Considering that the same culture medium and carbon source were used for both studies using the same $A$. ochraceus strain, the difference observed in the enzyme production can be justified by the morphological differences between biofilm and free mycelia. The production of enzymes is dependent on the fungal morphology [27]. Villena and Gutiérrez-Correa (2012) [28] also reported higher production of cellulase and xylanase by $A$. niger using biofilm system than that obtained though submerged fermentation. The production obtained using biofilm which was developed in Mineral medium and transferred to the Khanna medium $(0.16 \mathrm{U} / \mathrm{ml}$ and $5.31 \mathrm{U} / \mathrm{mg}$ of protein) was also significant. The Khanna medium was also used for tannase production by A. ochraceus [26], Aspergillus sp. [29] and A. japonicus 246A [30]. Other media also have been used for tannase production such as Czapeck medium for A. niger [31] and Mineral medium for A. fumigatus CAS21 [32].

Fig. 1 illustrates the fungal development on the polyethylene inert support to form biofilm. With $24 \mathrm{~h}$ of development, it is possible to observe the initial elongation of the hyphae, indicating that the adhesion of the spore on the support surface was effective. This adhesion depends on the specific proteins known as adhesines [33]. A massive fungal growth is obtained at $48 \mathrm{~h}$ and the conidiophores are present. At $72 \mathrm{~h}$, a dense mycelial matrix can be observed, with many channels (indicated by arrows) that facilitate the fungal nutrition and mass exchange. The same
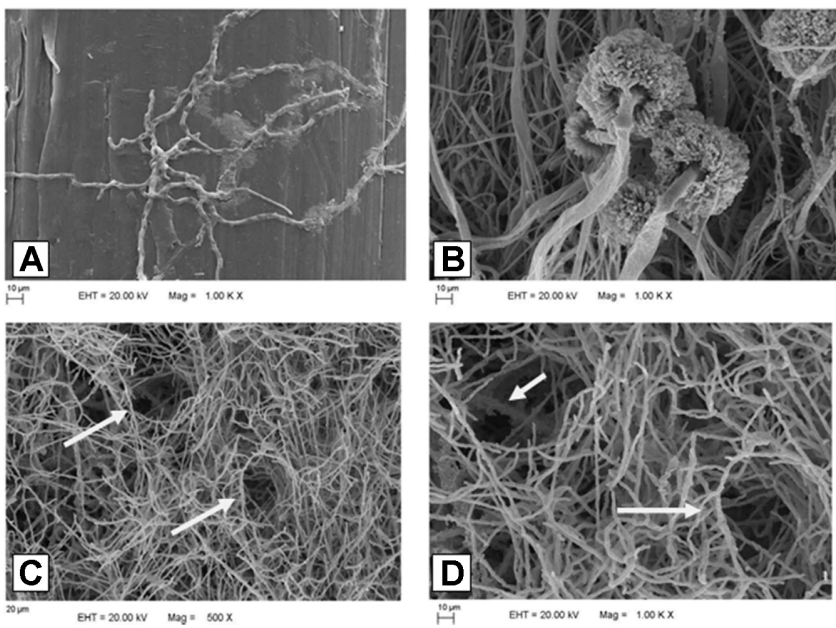

Fig. 1. SEM micrographs of the A. ochraceus biofilm on polyethylene inert support developed for $24 \mathrm{~h}$ (A), $48 \mathrm{~h}$ (B), and $72 \mathrm{~h}(\mathbf{C}$ and $\mathbf{D})$.

The arrows indicate the channels in the mycelial organization. 
morphologic characteristics were also observed for the A. niger [34] and R. microsporus [14] biofilms. According to Harding et al. (2009) [33], some phases can be identified during the fungal biofilm formation: adsorption, attachment, formation of microcolony I, formation of microcolony II, formation of the mature biofilm, and dispersal phase.

It is important to consider that the production of enzymes and other metabolites in an industrial context is dependent on the fungal morphology. The filamentous fungi grow according to two main morphological standards, dispersed morphology and spherical hyphal aggregates (pellets) [27]. During the biofilm formation, the dispersed morphology is clear, contributing for enzyme secretion. On the other hand, in the spherical pellets there are limitations in diffusive mass transfer, lowering nutrients and oxygen levels [27], what is not observed in fungal biofilm. In spite of the clear relation between enzyme production and fungal morphology, different question should be solved to full understanding of this phenomenon.

Considering the potential of fungal biofilm for production of enzymes under an industrial scene, its reuse for successive cycles of production of the aimed molecule is an attractive way to minimize cost of the process. The reuse of the $A$. ochaceus biofilm allowed the tannase production for 3 consecutive cycles (data not shown), reinforcing the biotechnological potential of the fungal biofilm for enzyme production. The reuse of fungal biofilm was also reported by Mussato et al. (2009) [15] for the production of $\beta$ fructofuranosidase by Aspergillus japonicus developed on vegetable fibers carried out for 8 consecutive cycles.

\section{Influence of Carbon and Nitrogen Sources on Enzyme Production by A. ochraceus Biofilm}

Considering that the production of the most of tannases are inducible, the influence of different carbon sources added to the Khanna medium used for enzyme production was analyzed (Table 2). The highest production of tannase by $A$. ochraceus biofilm was achieved using gallic acid as carbon source, followed by tannic acid. The same was observed for the enzyme production by A. phoenicis [35]. Gallic acid was also reported as the main inducer for tannase synthesis by $A$. tamarii [36]. In the absence of carbon source and in presence of glucose, there is no tannase production, indicating any constitutive level of the enzyme. On the other hand, Lekha and Lonsane (1997) [37] suggested that the induction of the tannase production is similar to the induction of cellulases. Basal levels of enzyme are necessary to start the substrate hydrolysis, allowing the conditions for true induction. Phenolic
Table 2. Influence of different carbon sources on the production of extracellular tannases by A. ochraceus biofilm developed in Khanna medium and transferred to a new Khanna medium.

\begin{tabular}{lcc}
\hline \multirow{2}{*}{ Carbon source } & \multicolumn{2}{c}{ Tannase activity } \\
\cline { 2 - 3 } & $\mathrm{U} / \mathrm{ml}$ & $\mathrm{U} / \mathrm{mg}$ of protein \\
\hline None & 0 & 0 \\
Glucose & 0 & 0 \\
Green tea leaves & $0.04 \pm 0.02$ & $0.27 \pm 0.12$ \\
Tannic acid & $0.31 \pm 0.03$ & $17.62 \pm 1.22$ \\
Gallic acid & $0.40 \pm 0.04$ & $19.32 \pm 5.25$ \\
Mint leaves & $0.04 \pm 0.05$ & $0.29 \pm 0.05$ \\
\hline
\end{tabular}

The cultures for enzyme production were developed in Khanna medium for $72 \mathrm{~h}$ at $28^{\circ} \mathrm{C}$ with agitation $(50 \mathrm{rpm})$

compounds such as gallic acid, pyrogallol, methyl gallate, and tannic acid can induce tannase synthesis [38]. According to Aguilar and Gutierrez-Sánchez (2001) [39], the tannic acid is a big molecule which cannot cross the microbial cell membrane. Therefore, an intermediary compound obtained from the tannic acid hydrolysis could act as a true inducer.

When leaves such as green tea and mint were used, the production of tannase was reduced. Plant leaves can present different quantity of phenolic compounds depending upon the plant species, parts, harvest period, and environmental conditions. According their structures, the vascular plant tannins are classified as hydrolysable tannins, condensed and complex tannins [40]. The proportion among these types of tannins is also varied according to the plant species, what can affect differently the induction of tannase production. In addition, the microbial degradation of plant tannins depends on the type of microorganism, specifically filamentous fungus. Another possibility is that it is too short of a period for fungal cultivation to obtain sufficient quantities of tannase using plant leaves.

Considering the best production conditions obtained with tannic acid and gallic acid, the influence of the cultivation time on the enzyme production using different carbon sources was analyzed (Fig. 2A). The highest enzyme production was obtained in the presence of gallic acid with $72 \mathrm{~h}$ of cultivation. However, tannase production in the presence of tannic acid for $48 \mathrm{~h}$ cultivation was higher than that observed when gallic acid was used. The influence of the concentrations of both tannic acid and gallic acid added to the Khanna medium on the enzyme production by A. ochraceus biofilm was also analyzed after $72 \mathrm{~h}$ cultivation (Fig. 2B). As observed, the best enzyme production was achieved using $1.5 \%(\mathrm{w} / \mathrm{v})$ tannic acid $(33.61 \mathrm{U} / \mathrm{mg}$ of 

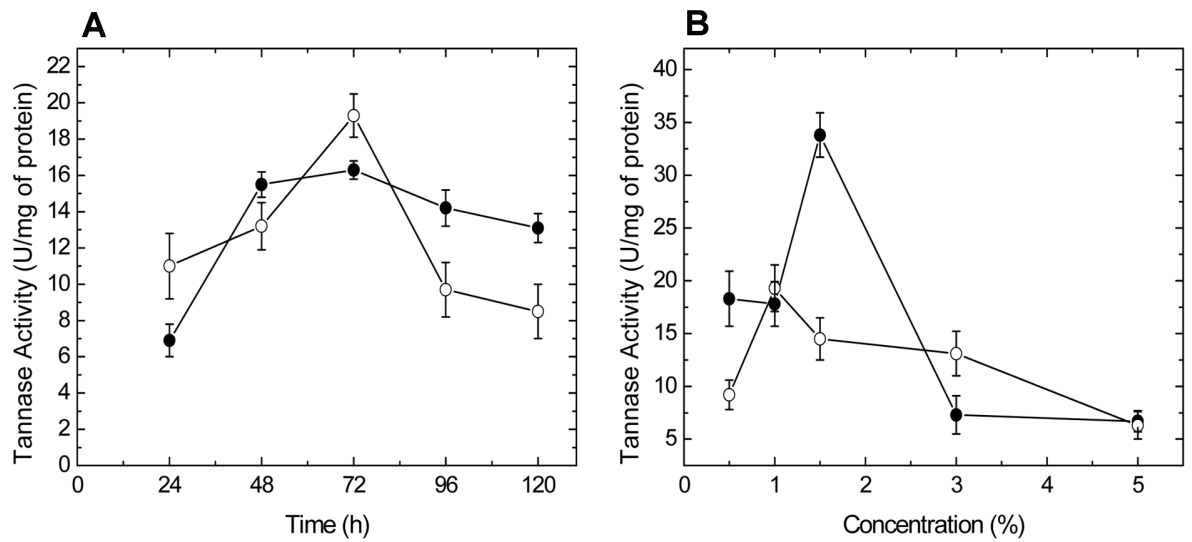

Fig. 2. Influence of fermentation period (A) and carbon source concentration (B) on tannase production by A. ochraceus biofilm in Khanna medium containing tannic acid $(\mathbf{O})$ and gallic acid $(\bigcirc)$ as carbon sources.

protein). It was 30-fold higher than that obtained using submerged fermentation for the same fungus [26]. In the presence of tannic acid higher than $1.5 \%(\mathrm{w} / \mathrm{v})$, the enzyme production declined. Tannic acid at high levels can link irreversibly with the proteins in cell surface inhibiting microbial growth and enzyme production. The same can occur at high gallic acid concentrations [31]. Considering gallic acid as the carbon source, the best production was obtained using $1 \%(\mathrm{w} / \mathrm{v})$ of the compound. At this concentration, the enzyme production using gallic acid exceeds that obtained with tannic acid.

Fig. 3A depicts the influence of different nitrogen sources on the production of tannase by $A$. ochraceus biofilm. The best enzyme production as obtained using yeast extract (24.96 U/mg of protein), while the minor production was observed in the presence of casein $(7.46 \mathrm{U} / \mathrm{mg}$ of protein). The reduced tannase production in the presence of casein can be explained by the presence of proteases. Increase in the protease production, induced by casein [41], can promote hydrolysis of tannases. The same occurred when beef extract was added to the culture medium. Considering the best production of tannase using yeast extract, it is notable that the high enzyme production was obtained using $0.1 \%(\mathrm{w} / \mathrm{v})$ of this nitrogen source (Fig. 3B). In general, the yeast extract contains proteins $(48.52 \%)$, carbohydrates $(32.92 \%)$, minerals $(8.32 \%)$, RNA $(7.52 \%)$, and lipids (3.4\%) [42]. According to this observation, concentrations of yeast extract $\geq 0.2 \%(\mathrm{w} / \mathrm{v})$ can provide all nutrients for fungal development without the necessity to use tannic acid, thereby drastically reducing the production of tannase. The use of additional nitrogen sources to increase the tannase production was also reported for A. fumigatus CAS21 [32] and A. phoenicis [35]. Addition of inorganic nitrogen sources have been reported for tannase production in $A$. niger with $\mathrm{NH}_{4} \mathrm{NO}_{3}$ [43], and in A. niger Van Tieghem with $\mathrm{NaNO}_{3}$ [44].

B

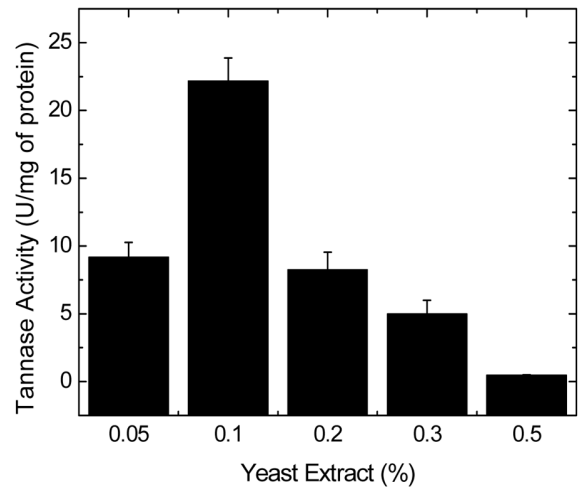

Fig. 3. Influence of different nitrogen sources (A) and concentration of yeast extract (B) on the production of tannase by A. ochraceus biofilm in Khanna medium containing tannic acid as carbon source, for $72 \mathrm{~h}$ at $28^{\circ} \mathrm{C}$. 

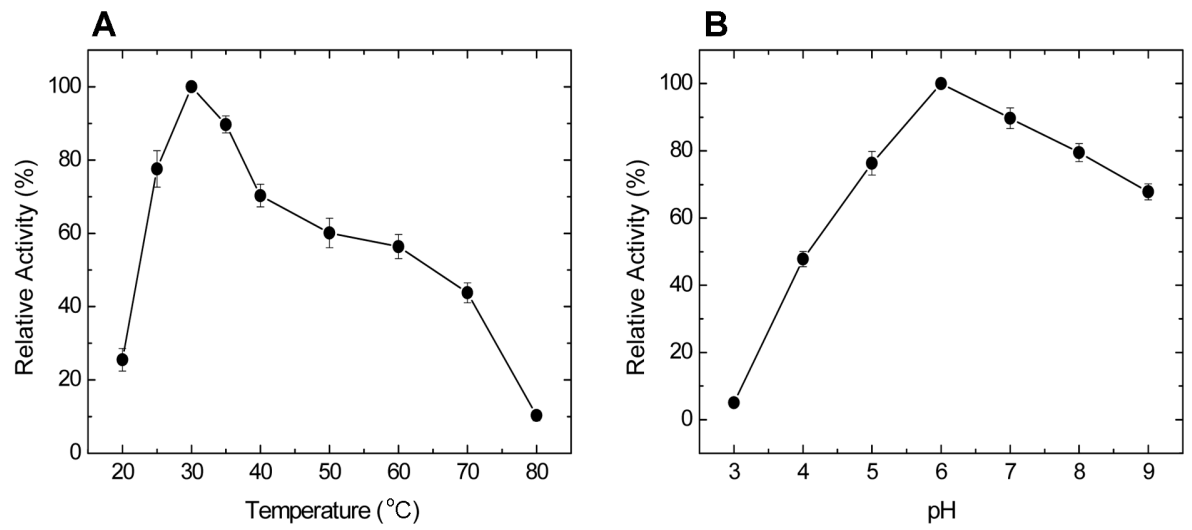

Fig. 4. Influence of the temperature $(\mathbf{A})$ and $\mathrm{pH}(\mathbf{B})$ of the reaction on tannase produced by A. ochraceus biofilm.

\section{Influence of $\mathrm{pH}$ and Temperature on Tannase Activity}

The best temperature and $\mathrm{pH}$ for activity of the tannase present in the crude filtrate obtained from the $A$. ochraceus biofilm cultivation was $30^{\circ} \mathrm{C}$ and $\mathrm{pH} 6.0$, respectively (Fig. 4). This is different from that observed for the enzyme obtained in submerged fermentation $\left(40^{\circ} \mathrm{C}\right.$ and $\mathrm{pH}$ 6.0) [26]. In general, tannases are characterized as acidic enzymes with highest activity at $\mathrm{pH} 5.5$ [17], in a temperature range of $20-60^{\circ} \mathrm{C}$, with best activity at $35^{\circ} \mathrm{C}$ [32]. The best activity for the tannase from $A$. tamarii was observed at $30^{\circ} \mathrm{C}$ and $\mathrm{pH} 5.0$ [36]. The best temperature and $\mathrm{pH}$ for the highest tannase activity from Aspergillus aculeatus was at $60^{\circ} \mathrm{C}$ and $\mathrm{pH}$ 5.0, respectively [45]. Considering A. ochraceus, the difference in the production between biofilm fermentation and submerged fermentation can be explained by differential gene expression. During the biofilm formation, mycelia adhere onto a solid surface resulting in different phenotypes, especially morphology and production of different molecules. In contrast, during submerged fermentation, mycelia are free [33].

\section{Influence of Different Compounds on Tannase Activity}

The influence of organic solvents, denaturing agents, chelating agents, and surfactants on tannase activity was also analyzed (Table 3). In presence of Triton X-100, Tween 20, and SDS the enzyme activity was not affected significantly. This was also observed for the organic solvents, with the exception of butanol that reduced the tannase activity (-38.4\%). From a biotechnological standpoint, the use of organic solvents can be advantageous because they promote high solubility of the most of organic compounds in non-aqueous media, improve enzyme stability, facilitate the recuperation of the product, increase the solubility of the non-polar substrates, reduce the collateral effects of the aqueous reactions, and minimize the microbial contamination [46].

The denaturing agent, $\beta$-mercaptoethanol, reduced the enzyme activity $(-13.5 \%)$. This effect was also observed for the enzyme production by co-culture of Rhizopus oryzae and $A$. foetidus, and by $A$. niger cultivation [47]. This agent breakdowns the disulfide bonds in the protein structure, thereby reducing its activity [48]. The chelating agent EDTA also reduced $(-18.2 \%)$ the tannase activity from A. ochraceus biofilm as also reported for Verticillium sp. [49]. On the other hand, addition of urea to the reaction at reduced concentrations, promoted increase $(+18.2 \%)$ in the tannase activity as also observed by Cavalcanti et al. (2018) [12] for the enzyme produced by A. fumigatus CAS21. At high concentrations of urea, the protein hydrogen bonds

Table 3. Effect of different compounds on extracellular tannase activity from $A$. ochraceus biofilm.

\begin{tabular}{lc}
\hline \multicolumn{1}{c}{ Compounds } & Relative tannase activity (\%) \\
\hline Control & 100 \\
Ethanol (1\%) & $102.4 \pm 4.0$ \\
Methanol (1\%) & $103.7 \pm 3.4$ \\
Acetonitrila (1\%) & $101.0 \pm 6.2$ \\
Isopropanol (1\%) & $92.8 \pm 6.5$ \\
Butanol (1\%) & $61.6 \pm 3.2$ \\
Acetone (1\%) & $90.3 \pm 5.6$ \\
Triton X-100 $(0,01 \%)$ & $105.6 \pm 3.9$ \\
Tween - 20 (0,01\%) & $94.4 \pm 4.1$ \\
SDS $\left(1 \mathrm{mmol} \mathrm{l}^{-1}\right)$ & $104.3 \pm 8.0$ \\
$\beta$-mercaptoethanol $\left(1 \mathrm{mmol}^{-1}\right)$ & $86.5 \pm 4.8$ \\
Urea $\left(1 \mathrm{mmol} \mathrm{l}^{-1}\right)$ & $118.4 \pm 7.7$ \\
EDTA $\left(1 \mathrm{mmol} \mathrm{l}^{-1}\right)$ & $81.7 \pm 4.1$ \\
\hline
\end{tabular}

$100 \%=15.3 \pm 0.8 \mathrm{U} / \mathrm{mg}$ of protein. 
are affected in turn promoting conformational modification in the molecular structure and, consequently, denaturation [50]. The ability of the tannase produced by A. ochraceus biofilm to be stable in the presence of solvents, surfactants, and denaturing agents highlights the enzyme's potential to be used in a wide range of applications.

\section{Potential of Enzyme Application}

Effluent treatment. The leather industry is responsible for generation of high volumes of effluents containing tannins and other organic molecules, that contribute to environmental pollution. The use of tannases to treat rich tannin effluents represents an interesting possibility to minimize their negative effects on the environment. Therefore, the potential of the tannase produced by $A$. ochraceus biofilm to reduce the tannins and total phenolic compounds in leather effluent was evaluated. The use of the enzyme reduced tannin content about $83.64 \%$ and $56.41 \%$ in the effluents produced through the manual and mechanical processes of leather preparation, respectively (Fig. 5). In the case of total phenolic compounds, the enzymatic treatment reduced the content of these compounds at $47.6 \%$ and $64.44 \%$ in the effluents from mechanical and manual processes, respectively. The tannase produced by $A$. fumigatus CAS21 also reduced the tannin content from leather effluents, especially that produced by manual process [12]. The difference observed for the reduction of the tannins content for the effluents from manual and mechanical processes, after enzyme treatment, can be justified by the composition of each one.

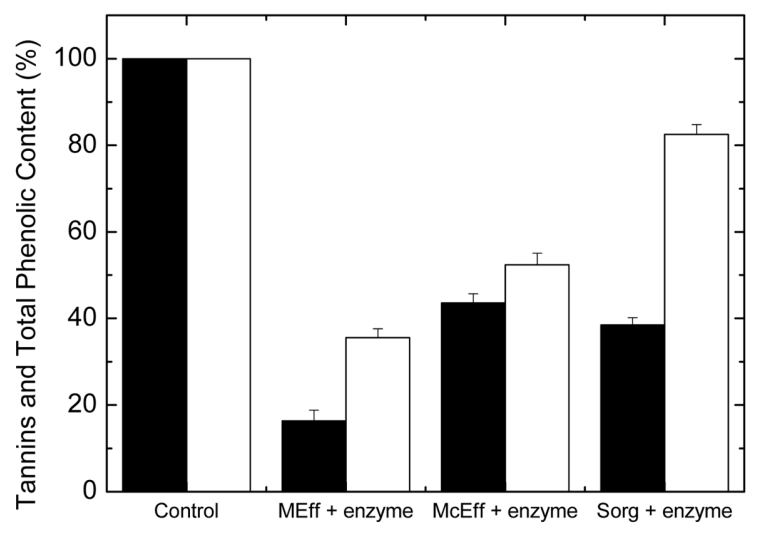

Fig. 5. Effect of enzymatic treatment using tannase produced by $A$. ochraceus biofilm on the tannins ( $\mathbf{\square})$ and phenolic compounds $(\square)$ from the leather effluents from manual (MEff) and machine (McEff) process, as well as from sorghum grains (Sorg).
In the manual process, the treatment is conducted using only angico peels (Anadenanthera colubrina Vell.), while in the mechanical tanning, the treatment is performed with soybean oil, cotton oil and tannin powder from angico.

Sorghum treatment. The sorghum is an important constituent in animal feed. It has a high concentration of soluble carbohydrates, a factor that contributes to the nutritional quality of the feed [51]. However, some varieties of this species present anti-nutritional factors such as tannins, which form complex with proteins and minerals, and thereby reduce the digestibility and nutritional value of the grains [25]. The application of tannase to minimize this situation is an interesting alternative for the animal feed preparation.

The contents of tannins and phenolic compounds of the sorghum meal were reduced to $61.31 \%$ and $17.49 \%$, respectively, after enzymatic treatment for $120 \mathrm{~h}$ using tannase produced by A. ochraceus biofilm (Fig. 5). Schons et al. (2012) [25] reported a reduction of $92 \%$ and $66 \%$ in the content of tannins and phenolic compounds in the sorghum meal using the enzyme produced by $P$. variotii.

\section{Production of Propyl Gallate}

Fig. 6 shows the propyl gallate spectra obtained by FTIR after reactions catalyzed by tannase produced by A. ochraceus biofilm using tannic acid as a substrate in the presence of 1-propanol. Gallic acid is a precursor for propyl gallate synthesis through esterification reaction in the presence of 1-propanol. Propyl gallate spectra synthesized by tannase produced by $A$. ochraceus exhibited peaks similar to those found in commercial propyl gallate spectra (Fig. 1A). Peaks close to $2,970 \mathrm{~cm}^{-1}$ are attributed to the $\mathrm{CH}_{2}$ bond [52] and bands characteristic of the functional groups $\mathrm{C}=\mathrm{C}$ and $\mathrm{C}-\mathrm{O}$ were observed in regions close to 1,650 $1,600 \mathrm{~cm}^{-1}$ and $1,300-1,000 \mathrm{~cm}^{-1}$, confirming the presence of propyl gallate molecules. Similar spectra have been reported for commercial propyl gallate (Merck, Germany) and tannase synthesized by A. awamori BTMFW021 [52]. In general, tannases catalyze hydrolytic reactions under aqueous environment. But, under organic conditions with or without reduced water, the reactions of esterification are predominant [53].

This is the first report of tannase obtained by fungal biofilm fermentation. The production of tannase by A. ochraceus biofilm was higher than that obtained using conventional submerged fermentation. The enzyme has potential to be used in leather effluent treatment, in propyl gallate synthesis, and as an ingredient in the feed formulation using sorghum grains. The biofilm fermentation 

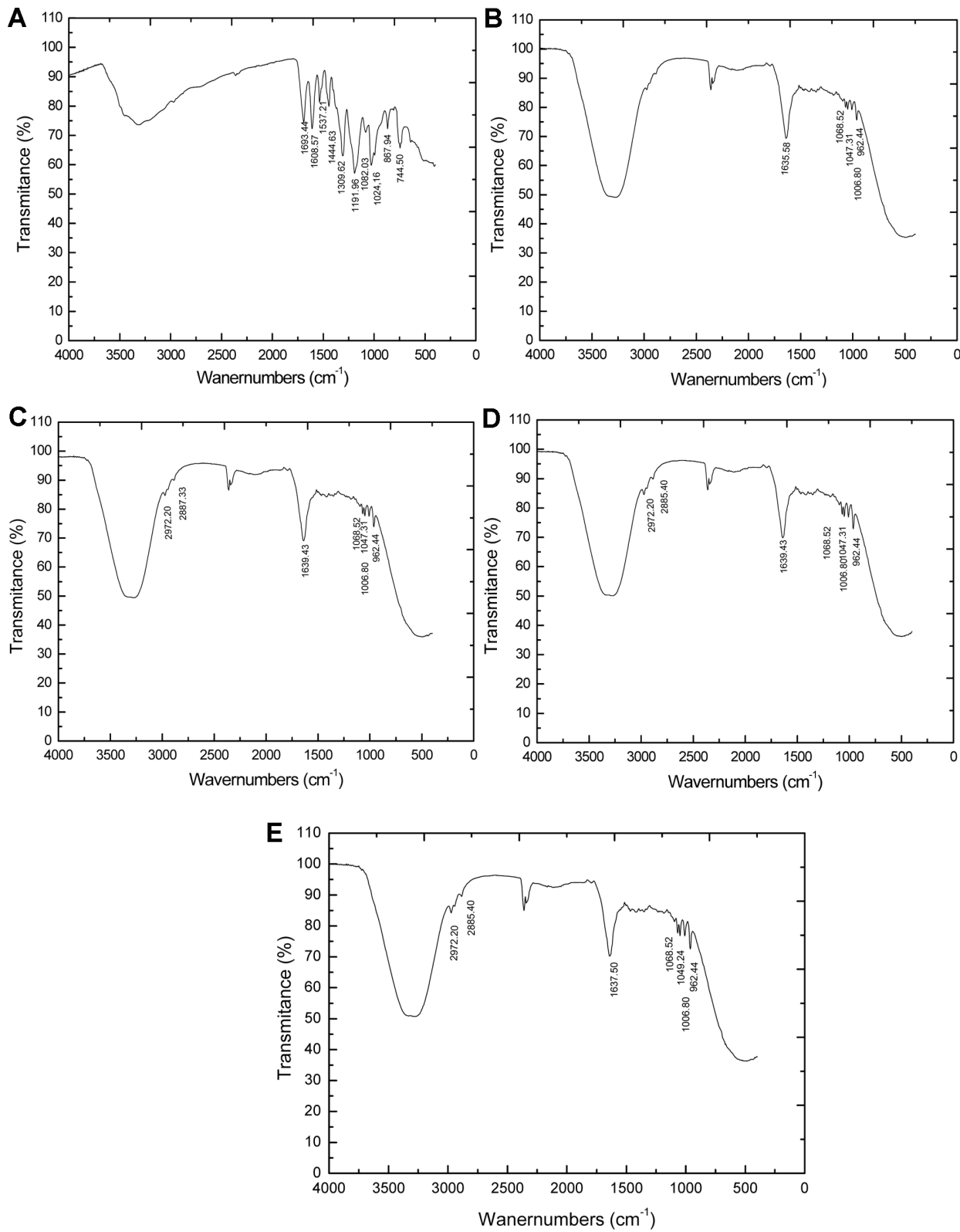

Fig. 6. FTIR spectra for the commercially available (A) and produced (B-E) propyl gallate using tannase produced by A. ochraceus biofilm, with $24 \mathrm{~h} \mathrm{(B),} 48 \mathrm{~h}(\mathbf{C}), 72 \mathrm{~h}(\mathbf{D})$, and $96 \mathrm{~h}(\mathrm{E})$ of transesterification reaction using tannic acid as a substrate in the presence of 1-propanol.

technology was confirmed as an attractive possibility to produce enzymes such as tannases.

\section{Acknowledgments}

The authors gratefully acknowledge the financial support from Fundação de Amparo à Pesquisa do Estado de São Paulo-FAPESP (Process no 2016/11311-5). We also thank Maurício de Oliveira for the technical assistance and Carlos Ambrosio from ARTEZA, who provided the effluent samples. The manuscript is part of the master dissertation of F.M.A. financed by Ministério da Ciência, Tecnologia, Inovações e Comunicações (CNPq). We also thank teacher Abilio Borghi for the grammar review of the manuscript. 


\section{Conflict of Interest}

The authors have no financial conflicts of interest to declare.

\section{References}

1. Frutos P, Hervás G, Giráldez FJ, Mantecón AR. 2004. Review. Tannins and ruminant nutrition. Spanish J. Agric. Res. 2: 191-202.

2. Banerjee D, Pati BR. 2007. Optimization of tannase production by Aureobasidium pullulans DBS66. J. Microbiol. Biotechnol. 17: 1049-1053.

3. Chávez-González M, Rodríguez-Duran LV, Balagurusamy N, Barragán-Prado A, Rodríguez R, Contreras CC, Aguilar CN. 2011. Biotechnological advances and challenges of tanase: An overview. Food Bioprocess Technol. 5: 445-459.

4. Gómez-Plaza E, Cano-López M. 2011. A review on microoxygenation of red wines: claims, benefits and the underlying chemistry. Food Chem. 125: 1131-1140.

5. Yao J, Guo GS, Ren GH, Liu YH. 2014. Production, characterization and applications of tannase. J. Mol. Cat. B: Enzymatic 101: 137-147.

6. Battestin V, Matsuda KL, Macedo AG. 2004. Fontes e aplicações de taninos e tanases em alimentos. Alimentos $e$ Nutrição 15: 63-72.

7. Patra A, Saxena J. 2010. A new perspective on the use of plant secondary metabolites to inhibit methanogenesis in the rumen. Phytochem 71: 1198-1222.

8. Rodríguez-Durán LV, Valdivia-Urdiales B, ContrerasEsquivel JC, Rodríguez-Herrera R, Aguilar CN. 2011. Novel strategies for upstream and downstream processing of tannin acyl hydrolase. Enzyme Res. 2011: 823619.

9. Raaman N, Mahendran B, Jaganathan C, Sukumar S, Chandrasekaran V. 2010. Optimasation of extracellular tannase production from Paecilomyces variotii. W. J. Microbiol. Biotechnol. 26: 1033-1039.

10. Beniwal V, Kumar A, Sharma J, Chhokar V. 2013. Recent advances in industrial application of tannases: a review. Recent Patents Biotechnol. 7: 228-233.

11. Kumar SS, Sreekumar R, Sabu A. 2018. Tannase and its applications in food processing. pp.357-381. In: B. Parameswaran, S. Varjani and S. Raveendran, eds. Green Bio-processes. Energy, Environment, and Sustainability. Singapore: Springer.

12. Cavalcanti RMF, Jorge JA, Guimarães LHS. 2018. Characterization of A. fumigatus CAS21 tannase with potential for propyl gallate synthesis and treatment of tannery effluent from leather industry. 3 Biotech 8: 270.

13. Gutiérrez-Correa $M$, Ludeña $Y$, Ramage G, Villena GK. 2012. Recent advances on filamentous fungal biofilms for industrial uses. Appl. Biochem. Biotechnol. 167: 1235-1253.
14. Sato VS, Jorge JA, Guimarães LHS. 2016. Characterization of a thermotolerant phytase produced by Rhizopus microsporus var. microsporus biofilm on an inert support using sugarcane bagasse as carbon source. Appl. Biochem. Biotechnol. 174: 610624.

15. Mussato SI, Rodrigues LR, Teixeira JA. 2009. $\beta$ Fructofuranosidase production by repeated batch fermentation with immobilized A. japonicus. J. Ind. Microbiol. Biotechnol. 36: 923-928.

16. Khanna P, Sundaril SS, Kumar NJ. 1995. Production, isolation and partial purification of xylanases from $A$. sp. W. J. Microbiol. Biotechnol. 11: 242-243.

17. Costa AM, Ribeiro WX, Kato E, Monteiro ARG, Peralta RM. 2008. Production of tannase by A. tamarii in submerged cultures. Braz. Arch. Biol. Technol. 51: 399-404.

18. Rizzatti ACS, Jorge JÁ, Terenzi HF, Rechia CGV, Polizeli MLTM. 2001. Purification and properties of thermostable extracellular $\alpha$-D-xylosidase produced by thermotolerant $A$. phoenicis. J. Ind. Microbiol. Biotechnol. 26: 156-160, 2001.

19. Wiseman, A. 1975. Handbook of enzyme biotechnology. pp.148. New York: John Wiley \& Sons.

20. Peralta RM, Terenzi HF, Jorge JA. 1990. $\beta$-D-glycosidase activities of Humicola grisea: biochemical and kinetic characterization of a multifunctional enzyme. Biochim. Biophys. Acta 1033: 243-249.

21. Sharma S, Bhat TK, Dawra RKA. 2000. Spectrophotometric method for assay of tannase using rhodanine. Anal. Biochem. 279: 85-89.

22. Bradford MM. 1976. A rapid and sensitive method for the quantitation of microgram quantities of protein utilizing the principle of protein-dye binding. Anal. Biochem. 72: 248-254.

23. Hagerman AE, Butler LG. 1978. Protein precipitation method for the quantitative determination of tannins. J. Agric. Food Chem. 26: 809-812.

24. Rao S, Santhakumar AB, Chinkwo KA, Wu G, Johnson SK, Blanchard CL. 2018. Characterization of phenolic compounds and antioxidant activity in sorghum grains. J. Cereal Sci. 84: 103-111.

25. Schons PF, Battestin V, Macedo GA. 2012. Fermentation and enzyme treatments for sorghum. Braz. J. Microbiol. 1: 89-97.

26. Gonçalves HB, Riul AJ, Quiapin AC, Jorge JA, Guimarães LHS. 2012. Characterization of a thermostable extracellular tannase produced under submerged fermentation by $A$. ochraceus. Electr. J. Biotechnol. 15.

27. Antecka A, Bizukojc M, Ledakowicz S. 2016. Modern morphological engineering techniques for improving productivity of filamentous fungi in submerged cultures. World J. Microbiol. Biotechnol. 32: 193-201.

28. Villena GK, Gutiérrez-Correa M. 2012. Kinetic analysis of A. niger cellulase and xylanase production in biofilm and submerged fermentation. J. Microbiol. Biotechnol. Res. 2: 805814 . 
29. Melo AG, Pedroso RCF, Guimarães LHS, Alves JGLF, Dias ES, Resende MLV, et al. 2014. The optimization of $A$. sp. GM4 tannase production under submerged fermentation. Adv. Microbiol. 4: 143-150.

30. Bradoo S, Gupta R, Saxena RK. 1997. Parametric optimization and biochemical regulation of extracellular tannase from A. japonicus. Process Biochem. 32: 135-139.

31. Lal D, Shrivastava D, Verma HN, Gardner JJ. 2012. Production of Tannin Acyl Hydrolase (E.C. 3.1.1.20) from A. niger isolated from bark of Acacia nilotica. J. Microbiol. Biotechnol. Res. 2: 566-572.

32. Cavalcanti RMF, Ornela PHO, Jorge JA, Guimarães LHS. 2017. Screening, selection and optimization of the culture conditions for tannase production by endophytic fungi Isolated from caatinga. J. Appl. Biol. Biotechnol. 5: 1-9.

33. Harding MW, Marques LL, Howard RJ, Olson ME. 2009. Can filamentous fungi form biofilms? Trends Microbiol. 17: 475-480.

34. Villena GK, Gutierrez-Correa M. 2006. Production of cellulase by $A$. niger biofilms developed on polyester cloth. Lett. Appl. Microbiol. 43: 262-268.

35. Riul AJ, Gonçalves HB, Jorge JA, Guimarães LHS. 2013. Characterization of a glucose- and solvent-tolerant extracellular tannase from A. phoenicis. J. Mol. Cat. B: Enzymatic. 85-86: 126-133.

36. Costa AM, Kadowaki MK, Minozzo MC, Souza CGM, Boer CG, Bracht A, et al. 2012. Production, purification and characterization of tannase from A. tamarii. Afr. J. Biotechnol. 11: 391-398.

37. Lekha PK, Lonsane BK. 1997. Production and application of tannin acyl hydrolase: state of the art. Adv. Appl. Microbiol. 44: 215-260.

38. Belmares R, Contreras-Esquivel JC, Rodriguez-Herrera R, Coronel AR, Aguilar CN. 2004. Microbial production of tannase: an enzyme with potential use in food industry. LWT- Food Sci. Technol. 37: 857-864.

39. Aguilar CN, Gutierrez-Sanchez G. 2001. Review: Sources, properties, applications and potential uses of tannin acyl hydrolase. Food Sci. Technol. Int. 7: 373-382.

40. Arbenz A, Avérous L. 2015. Chemical modification of tannins to elaborate aromatic biobased macromolecular architectures. Green Chem. 17: 2626-2646.

41. Rodarte MP, Dias DR, Vilela DM, Schwan RF. 2011. Proteolytic activities of bacteria, yeasts and filamentous fungi isolated from coffe fruit (Coffea arabica L.). Acta Scientiarum Agronomy 33: 457-464.
42. Caballero-Córdoba GM, Pacheco MTB, Sgarbieri VC. 1997. Composição química da biomassa de levedura integral (Saccharomyces sp.) e determinação do valor nutritivo da proteína em células íntegras ou rompidas mecanicamente. Food Sci. Technol. 17: 102-106.

43. George DS, Ong CB. 2013. Improvement of tannase production under submerged fermentation by A. niger FBT1 isolated from a mangrove forest. J. Biotechnol. Comput. Biol. Bionanotechnol. 94: 451-456.

44. Aboubakr HA, El-Sahn MA, El-Banna AA. 2013. Some factors affecting tannase production by $A$. niger Van Tieghem. Braz. J. Microbiol. 44: 559-567

45. Bagga J, Pramanik SK, Pandey V. 2015. Production and purification of tannase from A. aculeatus using plant derived raw tannin. Int. J. Sci. Eng. Technol. 4: 50-55.

46. Chhokar V, Sangwan M, Beniwal V, Nehra K, Nehra KS. 2010. Effect of additives on the activity of tannase from A. awamori MTCC9299. Appl. Biochem. Biotechnol. 160: 22562264.

47. Barthomeuf C, Regerat F, Pourrat H. 1994. Production, purification and characterization of a tannase from $A$. niger LCF 8. J. Ferment. Technol. 7: 320-323.

48. Mukherjee, G.; Banerjee, R. 2006. Effects of temperature, $\mathrm{pH}$ and additives on the activity of tannase produced by a coculture of Rhizopus oryzae and A. foetidus. W. J. Microbiol. Biotechnol. 22: 207-212.

49. Kasieczka-Burnecka M, Kuc K, Kalinowska H, Knap M, Turkiewicz M. 2007. Purification and characterization of two cold-adapted extracellular tannin acyl hydrolases from an Antarctic strain Verticillium sp. P9. J. Appl. Biol. Biotechnol. 77: 77-89.

50. Mahapatra K, Nanda RK, Baq SS, Banerjee R, Pandey A, Szakacs G. 2005. Purification, characterization and some studies on secondary structure of tannase from A. awamori nakazawa. Process Biochem. 40: 3251-3254.

51. Tolentino DC, Rodrigue JAS, Pires DAD, Veriato FT, Lima LOB, Moura MMA. 2016. The quality of silage of different sorghum genotypes. Acta Scientiarum Anim. Sci. 38: 143-149.

52. Beena PS, Basheer SM, Bhat SG, Bahkali AH, Chandrasekaran M. 2011. Propyl gallate synthesis using acidophilic tannase and simultaneous production of tannase and gallic acid by marine A. awamori BTMFW032. Appl. Biochem. Biotechnol. 164: $612-628$.

53. Pinto GAS, Gouri S, Leite SGF, Brito ES. 2005. Tanase: conceitos, produção e aplicação. Boletim do Centro de Pesquisa e Processamento de Alimentos 23: 435-462. 